\title{
Reconstructing the Mode of College English Writing Teaching with Information Technology
}

\author{
Ge Liu', a and Yandong Qu², b \\ ${ }^{1}$ Bohai University, Jinzhou 121003, China; \\ Liaoning University of Technology, Jinzhou 121001, China \\ alg781115@163.com, bplxfeng2009@sohu.com
}

Keywords: Big data era, Foreign language teachers, English writing, Information technology.

\begin{abstract}
As an important aspect of complex cognitive activity, English writing is regarded as the difficult part in college English teaching. The popularity of Internet and mobile terminals marks a new era of big data, which has significantly changed the ways of thinking and learning, and also brings new opportunities to college English writing. Firstly, the major problems of conventional college English writing class were discussed in this paper. Secondly, in order to optimize teaching platform, and to achieve a seamless connection between teaching evaluation system and writing teaching, teaching plans of college English writing should be aimed at the applications of English in the big data era. Finally, some measures are suggested to reconstruct the mode of college English writing teaching with information technology.
\end{abstract}

\section{Introduction}

Writing is one of the central pillars of language learning and of major interest and concern to foreign language teachers, students and researchers. Since the early 1980's, researchers and reviewers have been investigating response to undergraduate students' English writing [1-2]. As an important aspect of complex cognitive activity, writing is looked on as the difficult part in college English teaching. With the development of society, writing is no longer just a means of reinforcing what has already been learnt or simply an aid to learn English, but a tool for people to communicate in the real world [3]. Learning to write in English is an uphill struggle for most non-English major undergraduate students in China [3]. It is difficult to cultivate the writing ability of undergraduate students in English teaching, because traditional undergraduate students' writing evaluated by teachers' subjective is not suitable for modern English writing teaching. The popularity of Internet and mobile terminals marks a new era of big data, which has significantly changed the ways of thinking and learning, and which also brings new opportunities to college English writing. Firstly, the major existing problems in conventional college English writing class were discussed. Secondly, teaching plans of college English writing should be aimed at the application of English to optimize teaching platform and to achieve a seamless connection between teaching evaluation system and writing teaching. Finally, some measures are suggested to reconstruct the mode of undergraduate English writing teaching with information technology.

\section{Current situation of college English writing teaching}

\section{(1) Ignoring college English writing in class}

As a basic communicative ability, writing ability has great impact on the later life of college students. It seems that the writing skills have been ignored in the actual teaching process for a long time. Though a variety of reading materials in class are helpful to English writing, writing class is often occupied by English reading teaching. Undergraduate students have no time to study English writing in class due to the unreasonable curriculum settings [4]. Therefore, undergraduate students are lack of basic abilities of English writing. In conclusion, traditional English writing mode can't meet today's college students' needs due to ignoring college English writing in class. 


\section{(2) Giving effective writing feedback wasting human resources}

College students are advocated to practice more in the traditional teaching process of college English writing. It is difficult to guarantee the quality of English writing, however. Many studies have reported that teacher writing feedback can not only promote students' writing revision and develop their English writing ability, but also stimulate and maintain students' motivation and interest in English writing [5-7]. It is not just about finding mistakes. It should offer students clear and specific guidance on how to improve their performance. Much of the feedback we provide for students simply isn't helpful [8]. Weaver found that most students complained their writing feedback was too general and vague with no suggestions for improvement [9]. Meanwhile, giving effective undergraduate student writing feedback wastes a lot of human resources. Great quantity of writing feedback from English teachers is the main reason for the difficulty of improving the abilities of English writing due to limited time to prepare the teaching plans. It is important to keep the balance between positive and negative and offer specific positive comments along with specific negative comments.

\section{(3) Lack of perfect evaluation systems of writing}

Checking English writing is heavy manual marking process in the traditional college English teaching. A lot of drawbacks are left. For example, foreign language teachers pay more attention to vocabulary, grammar patterns and words of explanation in class, students need to spend more time on the composition of sentence correction after class, and practical writing training time of undergraduate students is rare. Students' assignments are mostly checked by foreign English teachers according to their own subjective consciousness. They can't timely feed the corrected assignments back to students. That is, college English writing lacks a perfect writing evaluation system.

\section{Opportunities for college English Writing}

The popularity of Internet and mobile terminals marks a new era of big data, which has significantly changed the ways of thinking and learning, and also brings new opportunities to college English writing. The main new opportunities are as follows:

\section{(1) Abundant writing teaching resources}

College English teachers and undergraduate students can get abundant writing materials, such as the latest lectures of experts, and the latest teaching video via Internet. If we could make full use of these teaching resources, the undergraduate students' writing abilities could be greatly improved. We are all in the network era, and English writing in computer could basically instead of writing on paper. We have been accustomed to the use of computers to handle the daily affairs, which naturally improve the efficiency of our work. It is very convenient for us to expand the English vocabulary, and grammar structure. It also can improve undergraduate students' English competence and save time of writing.

\section{(2) More perfect writing evaluation system}

In the current writing assessment, students' assignments are mostly assigned by their English teachers according to their own subjective consciousness. The evaluate way of English writing is not objective. Meanwhile, students can't get their feedback from their teachers timely. In the big data era, foreign language teachers can organize online discussion, so that students can express their views online, which can be evaluated by others. Many studies have showed that the student-to-student evaluation can greatly improve the positive initiative. In addition, big data can also provide us all kinds of automatic intelligent evaluation systems. Those writing teaching evaluation systems should closely combine with English writing teaching in the era of big data.

\section{(3) Optimization college English teaching platform}

All of teaching plans of college English writing should be aimed at the applications of English under the background of Big Data. By conformity of resources and consummation of function, the 
multi-level experimental writing teaching system could be constructed in the big data era. A seamless connection between teaching evaluation system and writing teaching should be achieved by optimization of college English teaching platform.

\section{Measures to improve college English writing}

\section{(1) Adopting suitable strategies according to applications of English}

College English writing is the specific expressional form of language applications [10]. Reform teaching of College English writing strategies should be taken on the basis of application of English under the background of big data. English writing has a plentiful meaning and writing teaching can be no longer limited to teaching materials. English teachers and college students can get abundant writing materials, the latest expert lectures, and the latest teaching video via Internet. For example, when assigning homework to students to write book reviews, English teachers can give proper guidance to the students to write one passage on their favorite books with the purpose to introduce the books to other students. Then, the drafts on the favorite books of college students could be published in the network. It is necessary to find an effective way of mutual exchange of learning and sharing knowledge. In this way, students can easily discover the existing problems in writing, and check vacancy and holes, then English writing could be improved [11].

\section{(2) Constructing advanced automatic intelligent evaluation systems}

Traditional teachers' subjective evaluation of students' writing has long been not adapted to the modern writing teaching. Now English writing teaching can't be separated from modern education technology, all kinds of writing materials collection, all kinds of teaching resources in the classroom teaching activities of the organization, the students' works can not be separated from modern information technology. Advanced automatic intelligent evaluation system should be closely combined with English writing teaching in the big data era. It can be effective and timely to evaluate and feedback the students' works, which can greatly improve students' writing enthusiasm. Constructing intelligent evaluation system of writing teaching can effectively help English teachers assess students' writing process and writing results. English teachers can use it for technical analysis, to understand the students' learning, to grasp their learning difficulties. For example, they can view the student's online activities through large data, to understand their use in terms of vocabulary, sentence patterns, grammar, and then adjust teaching ideas.

\section{(4) Changing methods of writing feedback}

Traditional mode of English writing teaching is not too concerned about feedback from teachers. It lacks the interaction between English teachers and students, which cause the students can not correctly understand their writing level. Students are not satisfied with traditional English writing teaching process. In the big data era, a large number of automatic intelligent evaluation system come into sight. With the help of intelligent evaluation system in the big data era, students can easily understand their writing level. Teachers should encourage students to use the similar writing platform, such as correcting network to eliminate the anxiety of students in writing. English teachers can give effective online writing feedback to students timely.

\section{(5) Improving English writing level by online discussions}

With the help of big data, English teachers can use the network to organize online discussion, so that students can express their views on a topic, others can evaluate the views. Studies have showed that mutual evaluation can greatly improve the positive initiative of the evaluation, while the evaluation of people themselves can also be improved. English teachers should enhance the application abilities of information technology, and strengthen cooperation with information technology to improve the practical education of college English teaching. 


\section{Conclusion}

The popularity of Internet and mobile terminals marks a new era of big data, which has significantly changed the ways of thinking and learning, and also brings new opportunities and challenges to college English writing. The influence of big data on college English teaching and learning is so profound that traditional teaching mode can't meet students' needs. Here a number of strategies are offered to improve college English teaching in the big data era. English writing teaching can be no longer limited to teaching materials from English teachers, but also allows students to understand their writing level online. In conclusion, the influence of big data era on college English writing teaching is still in the initial stage. English teacher have heavy responsibilities for teaching reform of college English writing.

\section{Acknowledgements}

The authors acknowledge financial support from Social Science Foundation of Liaoning Province in China (grand no. L15AWW002).

\section{References}

[1] T. P. L. Kelly. An analysis of written Feedback on ESL students' writing. Procedia - Social and Behavioral Sciences, 2014,123:389 - 397.

[2] G. Hillocks. Research on written composition: new directions for teaching. Urbana, IL: ERIC Clearinghouse on Reading and Communication Skills and The National Conference on Research in English, 1986.

[3] H. Jiang. A Study on TBLT in College English Writing. International Conference on Social Science, Education Management and Sports Education, 2015.

[4] X. M. Zhu. Teachers development and its implicit for the foreign language major education reform. Journal of Anhui University(Philosophy and Social Sciences), 2012, 20(5):12-14.

[5] R. Zhang. A research on English majors' response to different types of teacher written feedback, Guangxi Normal University, 2014.

[6] Hyland F. \& Hyland K. Sugaring the pill: Praise and criticism in written feedback. Journal of Second Language Writing, 2001,10(3):185-212.

[7] Aronson L. Twelve tips for teaching reflection at all levels of medical education. Med Teach. 2011, 33: 200-205.

[8] Give your students better writing feedback. http://www.betterwritingfeedback.com.

[9] M. R.Weaver. Do students value feedback? Student perceptions of tutors' written responses. Assessment \& Evaluation in Higher Education, 2006, 31(3):379-394.

[10] Y. P. Zhang. Basic needs of university students attending college English classes. Journal of Beijing institute of education, 2010, 15(8):78-79.

[11] G. Chen. Practice and exploration of college English writing teaching reform under the background of big data, English Teacher, 2015, 11:46-48. 